\title{
Mainstreaming Disaster Risk Reduction and Climate Change Adaptation in Comprehensive Development Planning of the Cities in Nueva Ecija in the Philippines
}

\author{
Arneil G. Gabriel ${ }^{1} \cdot$ Patrick Neil M. Santiago $^{1} \cdot$ Rosemarie R. Casimiro $^{1}$
}

Accepted: 21 April 2021/Published online: 12 May 2021

(C) The Author(s) 2021

\begin{abstract}
Recent scientific consensus suggests that climate-related disasters are becoming more frequent and destructive. Consequently, increasing importance is given to disaster risk reduction (DRR) and climate change adaptation (CCA) in global governance. The projected global warming at $1.5{ }^{\circ} \mathrm{C}$ and the climate variability that the Philippine archipelago experiences make DRR-CCA the key priorities of both the national and local government units. In this study, we assessed and measured the degree of mainstreaming of DRR-CCA in the comprehensive development plans (CDPs) of the five component cities in the province of Nueva Ecija in the Philippines. These are among the areas in Central Luzon that are susceptible to hydrometeorological and geologic hazards. We distributed survey questionnaires to 25 employees of the local government units in the five component cities in Nueva Ecija who are directly involved in planning activities. We triangulated their responses using archival data (review of written policies and plans). The main findings of the study indicate that in spite the presence of laws and policies on DRR-CCA, their implementation is only in the preliminary stages. The results also provide insights to policymakers and future researchers on the challenges and opportunities influencing the systemic mainstreaming of DRR-CCA in the province.
\end{abstract}

Arneil G. Gabriel

gabrielarneil77@gmail.com

1 Department of Public Administration, Nueva Ecija

University of Science and Technology,

3100 Cabanatuan City, Philippines
Keywords Climate-related disasters - Global warming - Local development planning $\cdot$ Philippines $\cdot$ Southeast Asia

\section{Introduction}

Many communities across the globe are now facing the biggest challenge of the generation-the continuous environmental degradation and rising economic losses due to the effects of devastating calamities that are aggravated by warming of the Earth's surface and climate change (Scheffran and Battaglini 2011). According to the Intergovernmental Panel on Climate Change (IPCC 2018), the Earth's climate has transformed in the last 650,000 years. This is reflected in the $0.87{ }^{\circ} \mathrm{C}$ observed global mean surface temperature (from natural/atmospheric phenomenon) and $0.2{ }^{\circ} \mathrm{C}$ estimated anthropogenic warming (from human activities) per decade since the pre-industrial times (the 1700 s to the 1930s). With its current rate, global warming of $1.5^{\circ} \mathrm{C}$ above pre-industrial levels is projected by the year 2030 to 2052 .

In the recent decades, changes in weather and sea level temperature have intensified natural hazards (IPCC 2018). There has been more frequent occurrence of tropical storms, flooding, droughts, landslides, and other extreme weather events (CRED 2016). Published evidences also indicate that the net damage costs from these changes are likely to increase over time (UNISDR 2012). Extreme weather events cause instability problems for infrastructures, impair the productivity of croplands, and create serious damages in both urban and rural settlements (Güneralp et al. 2015; Rao et al. 2016). If not immediately addressed, such weather extremes may escalate into 
disasters that may greatly affect people's lives and their sources of livelihood.

For three years in a row (2016-2018), the Philippines ranked third among 171 countries on the World Risk Index. With a score of $52.46 \%$ on exposure, $52.78 \%$ on vulnerability, and an overall risk of $27.69 \%$, the Philippines is placed on the top three countries with the greatest risk to natural hazard-related disasters in 2018 (Heintze et al. 2018). The index reflects the country's exposure, risk, and vulnerability to natural hazard-related disasters. To come up with the mentioned scores, three parameters were examined and measured. These are the country's (1) coping capacity or level of preparedness and response capabilities; (2) adaptation or the ability to adjust and generate longterm strategies to abate the negative consequences of climate change; and (3) susceptibility in terms of the citizen's socioeconomic conditions.

The figures are not surprising since it has long been established that the Philippines is situated along the Pacific Ring of Fire where many earthquakes occur and volcanic activities are recorded, and the typhoon belt where tropical storms are formed and sustained (Center for Excellence in Disaster Management \& Humanitarian Assistance 2018). In year 2018 alone, record-breaking catastrophes were experienced in Southeast Asia including the Philippines. (Cambridge Centre for Risk Studies 2018). After Super Typhoon Yolanda in 2013, another super typhoon named Mangkhut (Ompong) hit the northern Philippines, Hong Kong, and coastal southeast China in September 2018, leaving 150 fatalities (ReliefWeb 2018).

Given the challenges posed by the global warming of $1.5{ }^{\circ} \mathrm{C}$ and the Philippines' standing as the third most disaster-prone countries in the world (Heintze et al. 2018), the inclusion of disaster risk reduction (DRR) and climate change adaptation (CCA) to local policies and plans emerged as the fitting strategy to minimize disaster losses and ensure sustainable development (Smit et al. 2001).

\subsection{Disaster Risk Reduction (DRR) and Climate Change Adaptation (CCA) Initiatives}

Disaster risk reduction includes all efforts that can reduce disaster risks. These may be done by analyzing the factors causing disasters, reducing exposure to hazards and risks, and minimizing the vulnerability of people and their livelihoods (IOM 2010). Climate change adaptation includes actions aimed at reducing the impacts of the unavoidable consequences of the rising surface temperatures and increasing incidence of natural calamities (IPCC 2013). Disaster risk reduction involves more complex processes that look into the root causes of the problem and vulnerability, be it physical, social, economic, or environmental in nature.
In some cases, vulnerability increases because people tend to resist change or institutions fail to create enabling environment for better planning and implementation of mitigating, preparedness, and response measures (Cuevas et al. 2016). The study of Gabriel and Mangahas (2017) affirms the importance of enabling environment in the local setting for coping with the effects of climate variation and protecting forest resources in the Indigenous peoples (IPs) / Indigenous cultural communities.

The Philippines has gone a long way in addressing climate change and disaster risks. While there were civil defense councils established during the Commonwealth (1930s) and Japanese occupation (1940s) periods, it was only in 1978 when a Presidential Decree (PD 1566) was issued to solidify the country's disaster preparedness and response initiatives. Yet, approaches to calamities in the 1970s are limited to rescue and relief distribution during and immediately after a calamity (NDRRMC and OCD Planning Division 2009). Due to the increasing death toll and economic losses from frequent calamities, policymakers during the mid-2000 shifted their management focus towards climate change adaptation and disaster risk reduction. From thereon, DRR and CCA gradually gained substantive local and international policy backing.

The landmark approval in 2009 of the Climate Change Act (Republic Act 9729); in 2010 of the National Disaster Risk Reduction and Management Act (Republic Act 10121); in 2005 of the Hyogo Framework for Action 2005-2015; and in 2015 of the Sendai Framework for Disaster Risk Reduction 2015-2030 and Paris Agreement on Climate Change, have reinvigorated and augmented the country's efforts toward building resilience among local communities and sectoral stakeholders (NDRRMC 2011a; PIDS 2017). These documents further stress the importance of community and multi-stakeholder approach to disaster management.

The enactment of the Climate Change Act of 2009 also paved the way for the creation of the Climate Change Commission (CCC), which was tasked to develop policies and coordinate government programs on climate change. The CCC was also tasked to spearhead the formulation of the road map for all CCA-related programs, otherwise known as the National Climate Change Action Plan (NCCAP) 2011-2028 (World Bank 2013). The NCCAP prioritizes concerns related to human and food security, water sufficiency, environmental and ecological stability, and sustainable energy (Climate Change Commission 2012).

Meanwhile, the disaster risk reduction and management (DRRM) activities in the country are now guided by four thematic pillars: (1) disaster prevention and mitigation; (2) preparedness; (3) response; and (4) recovery and rehabilitation. The Republic Act 10121's core aim of a "safer, 
adaptive, and disaster resilient Filipino communities toward sustainable development" is translated and mainstreamed in all aspects of national and local governance (NDRRMC 2011b; PIDS 2017). Common strategies include the enhancement of the national and local capacity to develop, manage, and administer projects that address emerging climatic concerns (NDRRMC 2011b; World Bank 2010) and foster improvements in development planning in the Philippines.

\subsection{Local Development Planning in Response to Climate Variability and Adaptation Measures}

Blakely and Leigh (2010) agreed that the preparation of the local plan is also about analysis and projection. At most, inclusive development planning takes into consideration the principles of social inclusion and sustainability. It also integrates different policies and programs at the local level to create synergies and promote participatory governance.

Republic Acts 10121 and 9729 are among the policies requiring the inclusion of DRR-CCA into the local development planning process. As mentioned in the Department of the Interior and Local Government's (DILG) Local Planning Illustrative Guide (2015), the Comprehensive Development Plan (CDP) is an action plan utilized by every local administration to develop and implement priority sectoral and cross-sectoral programs and projects.

All local government units in the Philippines are mandated under Section 106 of Republic Act 7160 or Local Government Code of 1991 to formulate a CDP. These are applicable to the different political and administrative divisions of the local government namely provincial (composed of two or more cities and governed by a Governor); city/municipal (composed of two or more barangays or towns and governed by a Mayor); and the barangay level (composed of villages and governed by Punong Barangay). The provincial and city/municipal development councils are headed by the Chief Executive (Governor/ Mayor) and are composed of the following members: Chairman of the Committee of Appropriation of the Sanggunian (local legislative body), the District Congressman (congressional representative), and the nongovernmental organizations (NGOs) operating within the city as members. Meanwhile, the barangay development councils (BDC) are composed of the Punong Barangay (barangay chief executive), Sangguniang Barangay members, District Congressman (congressional representative), NGOs / private sector / religious groups, and the Barangay Secretary as the secretariat (Republic of the Philippines 1991; DILG 2015).

The planning process begins with the provincial and city/municipal planning and development officers identifying the members of the core planning team. Included in the planning structure are the Local DRRM Officers (LDRRMOs) as advocate of DRR and CCA initiatives. The Comprehensive Development Plan (CDP) and the Local DRRM Plan (LDRRMP) are among the 33 locally-mandated plans that identify sectoral issues as well as the interventions to address them (DILG 2015).

One important feature of the local development process is its alignment with the set development direction of the next higher governmental structure. This process ensures that development plans are synchronized from the central office to every barangay in the archipelago under one development direction set by the National Economic and Development Authority (NEDA) Central Office under the Office of the President. The local development process is ideally a vertical collaboration between the local government unit and civil society. It is also characterized by horizontal collaboration between the communities participating in the budget planning (Climate Change Commission 2017).

The development direction set by the local executive department is charted by pouring resources to the plans through the Annual Investment Plan and Annual Budget Appropriations submitted by different departments. The plan and the budget appropriations are then reviewed by the members of the local development council and approved by the local Sanggunian following a budget hearing. The local development council also deliberates and approves the development plan and the corresponding budget. The process is expected to observe transparency and accountability (Gabriel 2017). Worth mentioning is the presence of civil society organizations (CSOs) that assure the integration of the interest of the communities in the local development plans. Once approved by the Sanggunian, the plan with corresponding budget is forwarded to the Office of the Local Chief Executive for implementation.

The mainstreaming of DRR and CCA to local development planning aims to reverse the vicious cycle of disasters and deter economic and environmental instability. Indeed, development planning helps local government units to systematically create enabling environment for sustainable development that meets people's needs. However, as Ojo (2005) points out, disaster management is seen only as an emergency doling exercise and not as integral part of development. Another problem that the country is facing is the local government units (LGUs)' low compliance to the preparation and submission of CDPs and therefore, the low submission rate of only $48.71 \%$ in 2015 (DILG 2015). Therefore, the presence of plans is not an absolute manifestation of lesser vulnerability nor higher level of readiness.

In spite all these, the country has already made progress in confronting climate change and disaster risks with the 
mainstreaming of DRR and CCA as starting point. The ability of communities and institutions to adapt to change (Smit and Wandel 2006) and to understand disaster risk are both indicators of development and measure of sustainability (UNISDR 2015). To this end, the Philippine government is faced with the challenge of making institutions and communities more proactive and resilient to the impacts of climate change.

It is in this context that our study examined the level of mainstreaming of DRR and CCA in the local development planning process of the component cities in the province of Nueva Ecija in the Philippines that are susceptible to natural hazards. We also investigated whether the characteristics of the cities (disaster risk profiles) have significant relationship with the inclusion of DRR and CCA in the comprehensive development plan. Finally, we discuss the findings of the study and their policy implications.

Through archived data, inputs from personnel of the local government units directly involved in the planning activities, and analysis of all data gathered, this study assessed the effectiveness of the existing policies and programs on DRR and CCA at the local level. Likewise, it sought to determine the areas needing improvement or emphasis towards more definite measures for the promotion of climate change actions on both local and international fronts.

\subsection{Conceptual Framework}

This study espouses the idea that DRR-CCA-inclusive local development planning contributes to the success of disaster risk management in the component cities of Nueva Ecija. We based this assumption from the National Disaster Risk Reduction and Management Framework (NDRRMF) (NDRRMC 2011a). The framework exemplifies that the mainstreaming of DRR and CCA into plans will result in (1) enhanced understanding of planning environment; (2) more realistic allocation of land; (3) inclusion of potential damages and casualties to development goals and targets; (4) prioritization of risk reduction measures; and (5) provision of budgetary resources to DRR programs and projects. The concept is further illustrated in Fig. 1

We used the NDRRMF as a framework of analysis, taking into consideration that it provides for a "comprehensive, multi-sectoral, inter-agency, and communitybased approach" (Congress of the Philippines 2010, Section 6a) to disaster risk reduction and management in the Philippines. The framework reflects the idea that the implementation of the thematic interventions will "substantially reduce loss of life and damage to social, economic and environmental assets" (NDRRMC 2011a, p. 3). The guiding principles cited from the Integrated Local Development Planning Methodology of UNDP (2011) and reflected in Fig. 2 were also used to guide the analysis of data (Fig. 3).

As the framework elucidates, sustainability and social inclusion are important dimensions of local development planning. Hence, this study used the same as yardstick in the evaluation of the significance of the contents of the local development plans to the situation in the locality (disaster risk profile) and on the sustainability of the plans.

\section{Methods}

In the sections that follow, we detail the study area, population, and sampling procedures to appropriately situate the research.

\subsection{The Study Area}

Nueva Ecija is a landlocked province in the Philippines located in Region III or Central Luzon. It has plains, mountains, and rivers and the greatest number of cities in Region III given the province's four districts comprised of 27 municipalities and 5 cities (PSA 2017).

The selection of the study area is influenced by the susceptibility of the province and its cities (Cabanatuan, Gapan, Palayan, San Jose, and Science City of Muñoz) to both hydrometeorological and geologic hazards. All the cities are specifically compounded with problems related to flooding due to the denudation of Sierra Mountain ranges within the province's borders. The increasing economic activities and population density of the cities also increase the communities' exposure to hazards. The disaster experiences of the cities and their potentials to counteract the negative impacts of disaster risks and climate change through development planning are also interesting.

The mainstreaming of DRR and CCA to the Comprehensive Development Plan (CDP) is mandated under Climate Change Act of 2009 and Philippine DRRM Act of 2010. The same is also treated as first line of defense against natural hazards and disasters. Thus, it is also interesting to probe deeper into the level of mainstreaming of DRR and CCA in the five cities of Nueva Ecija.

\subsection{Population and Sampling Procedure}

We distributed a structured survey questionnaire to 25 employees of the local government units in the five component cities in Nueva Ecija, Philippines in September 2018. Two respondents were from each City Planning and Development Office (CPDO) and three from each City Disaster Risk Reduction and Management Office (CDRRMO). They are purposively chosen to participate in the study for their direct involvement in the planning and 
Fig. 1 The Philippine Disaster Risk Reduction and Management Framework (NDRRM) for the mainstreaming of disaster risk reduction (DRR) and climate change adaption (CCA) into national and local plans

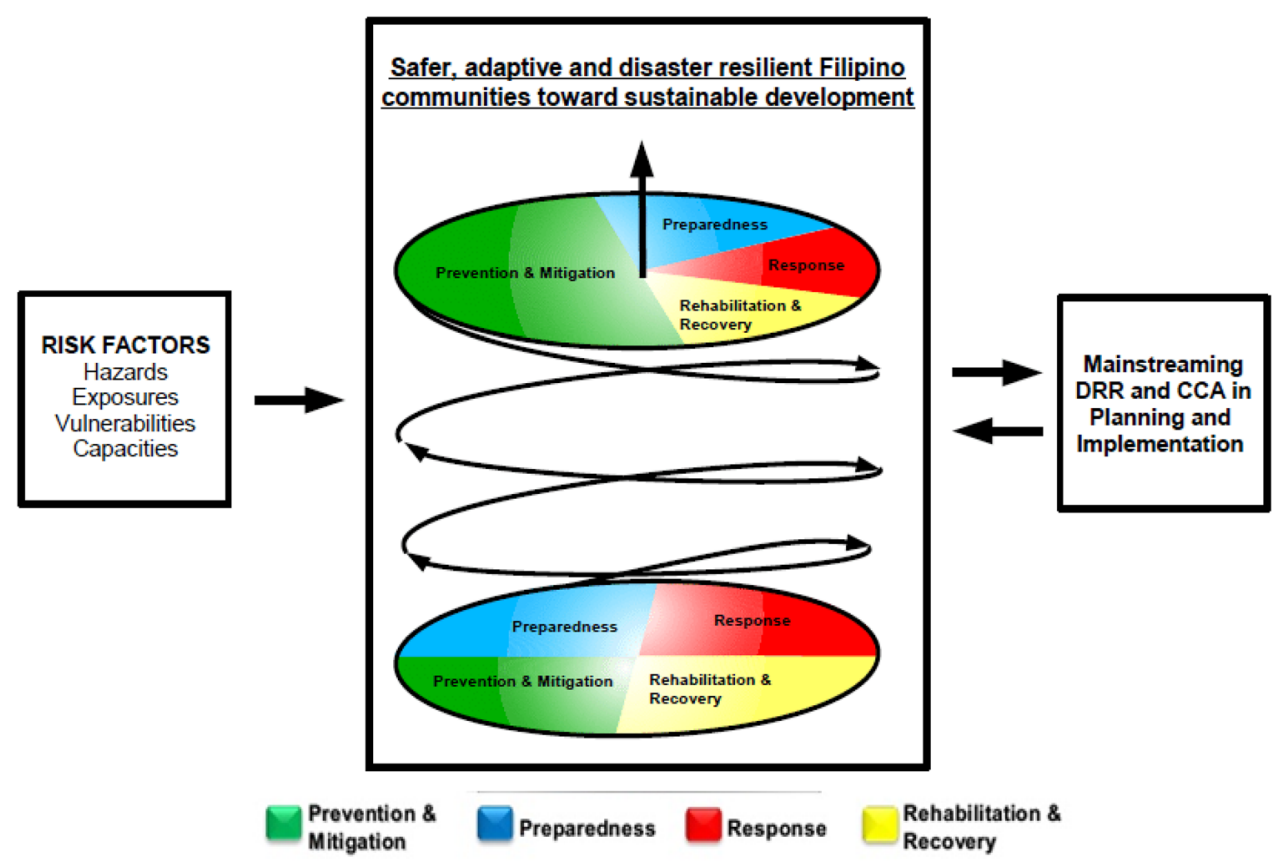

\section{Accountable environmental and natural resource management:}

Full awareness of the limitations of natural resources and environment-improvement of environment and ensuring that important natural resources are safe and saved for future generations.

\begin{tabular}{|c|c|}
\hline Sustainability & $\begin{array}{c}\text { Guiding principles for local } \\
\text { development planning }\end{array}$ \\
\cline { 2 - 3 }
\end{tabular}

Reaching sustainable economy:

Building a strong, dynamic, and sustainable economy that ensures the prosperity and opportunities for all, where environmental and social costs are borne by those who cause them and where efficient use of resources is stimulated.

\begin{abstract}
Building healthy and fair local community: Satisfying various needs of citizens, promoting personal security, social linkages and inclusion and enabling equal
\end{abstract} opportunities for all.

Continuous promotion of effective and participatory management systems - engaging civic creativity and energy.

Fig. 2 Dimensions of local development planning Source UNDP (2011).

preparation of the plan and for their capacity to provide the much-needed information on the topic under inquiry; therefore, increase the reliability of qualitative data (Tongco 2007). Furthermore, according to Palinkas et al. (2015), purposive sampling is the widely-used technique for the identification and selection of information-rich cases even with limited resources. This is particularly applicable to our study given the limited human resources in the mentioned offices at the time of data gathering.

The selection criteria for the respondents are: (1) Permanent employee of the CPDO and CDRRMO; (2) Having actual participation in the planning functions of their offices; and (3) Willing to participate in the study by answering the survey questionnaire and the interview questions. In-depth interviews were conducted to substantiate their responses to the questionnaires and to collect more information about the topic of this research.

We made use of a self-made questionnaire with four parts. The research instrument aimed to solicit information on the different adaptation practices employed in the local government units as follows: (1) the city's disaster risk profile; (2) respondent's profile; (3) level of awareness on the climate variability and extremes experienced in the last decades; and (4) inclusion of disaster risk reduction and climate change adaptation to local development planning. To solicit the most appropriate response, various techniques were employed. For items 1, 2, and 4, the respondents were asked to write down the specific answer, check the box related to an option, tick yes or no, or rank their answers. For item 3, the respondents' level of awareness was measured using a five-point Likert type scale. To test 
Fig. 3 Map of Nueva Ecija Source Google Maps.

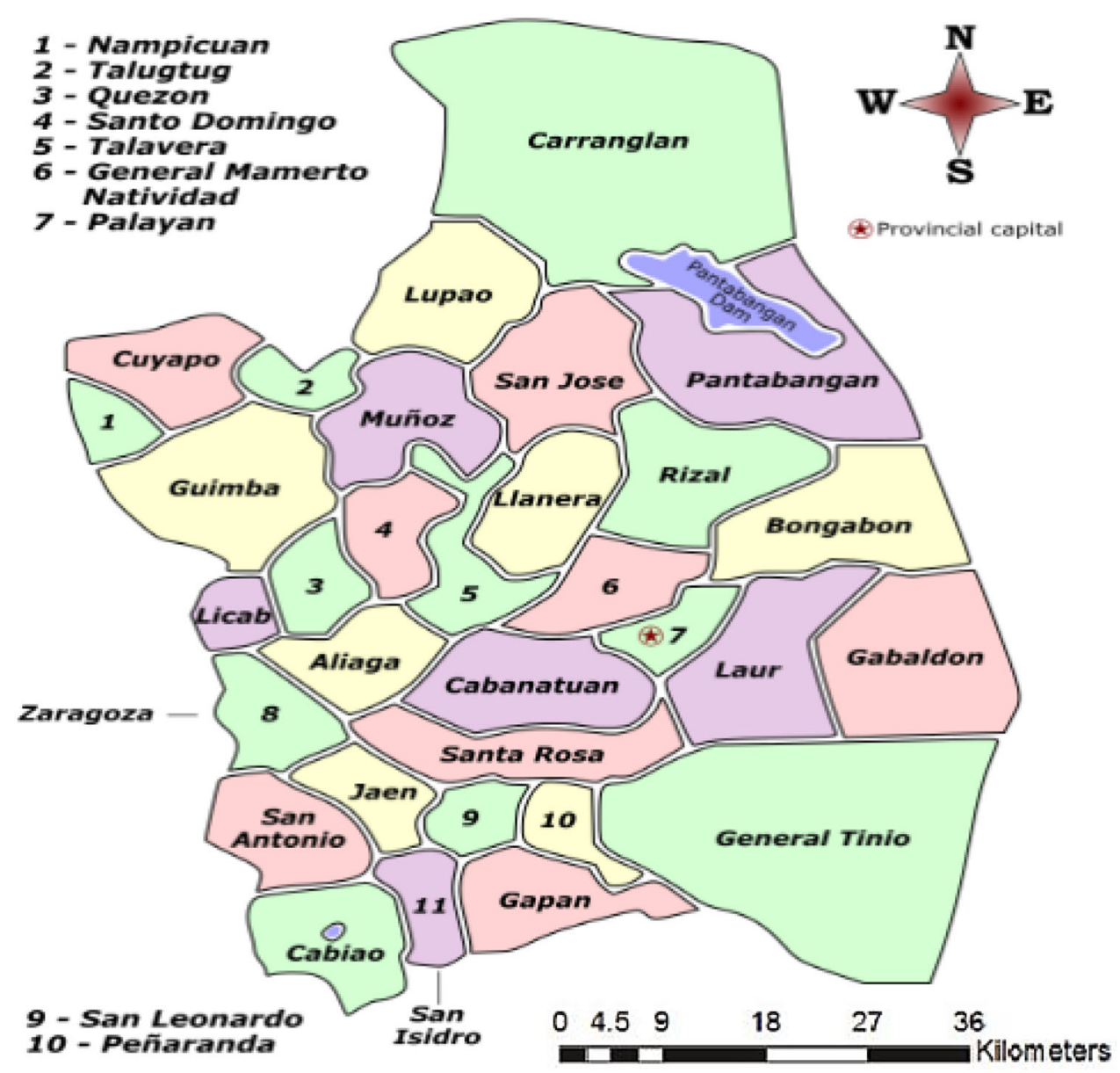

the validity and reliability of the instrument, a pilot testing was first conducted on 19 November 2018 in five municipalities of the province that are not covered by the study.

\section{Results and Discussion}

The study employed Spearman's rank correlation, a nonparametric test, to measure the degree of association between the variables on ordinal scale (Zhang et al. 2016). Each of the five cities was represented by five respondents. In terms of validity, the total sample size of $25 \mathrm{key}$ informants is treated as a valid sample size or representative of the population of personnel with direct involvement in the preparation of their respective CDPs. Also, it meets the minimum sample size requirement for Spearman's rank correlation analysis as supported by the study of Bonett and Wright (2000). The Spearman's rank correlation was interpreted based on Cohen's (1988) interpretation as follows: 0.10-0.29: Small/Weak; 0.30-0.49: Medium/ Moderate; 0.50-1.0: Large/Strong. The legend below is used in the presentation and analysis of data:

City A-Cabanatuan City
City B-Gapan City

City C_Palayan City

City D-San Jose City

City E-Science City of Muñoz

\subsection{Disaster Risk Profile of Cities}

The disaster risk as defined in the UNISDR (2015) Global Assessment Report is reflected in an equation in which hazard is multiplied by exposure and vulnerability and then divided by capacity or the level of preparedness. The variables in the equation were used to describe the disaster risk profiles of the five component cities of Nueva Ecija.

\subsubsection{Vulnerability}

Vulnerability is the human dimension of disasters (Twigg 2004). Just like exposure, it changes over time due to the influence of factors such as rapid urbanization, environmental degradation, market conditions, and demographic change (DFID 2004). One way to measure the vulnerability of an area is through its demographic characteristic in terms of the denseness of the population. 
City A, in spite of having the greatest number of barangays ( 89 barangays), is the most densely populated with 302,000 inhabitants, at a population density of 1571 persons per $\mathrm{km}^{2}$. Because of this, more people are likely to be affected by a calamity or at risk to impact of disasters. It also has the highest vulnerability to natural hazards and disasters, predominantly flooding. Although population density is not the sole indicator of vulnerability, the data show that as the population increases, so does the vulnerability of the community to disasters because of the increase in the number of potential losses and sufferers when disaster strikes (Hinkel 2011).

\subsubsection{Exposure}

The degree of exposure of a community is affected by factors such as population growth, migration, urbanization, and economic development. The existence of more hazards also increases the likelihood of people suffering from economic losses (UNISDR 2009). The number of barangays exposed to hazards and the degree of their exposure based on past disaster experiences were determined using pertinent data available in the CDRRMO and CPDO of each city; and the analysis of the respondents' answers to the interview and survey questionnaire. The statistics are presented in Fig. 4.

Almost all barangays of the component cities, except City $\mathrm{C}$ with high terrains, are exposed to the effects of typhoons, flooding, and earthquakes. At present, all cities are expanding their urban areas through the erection of more commercial and residential buildings. Unfortunately, these areas also have higher likelihood of incurring more economic losses once affected by calamities. City A, which is the most urbanized among the component cities, has the highest exposure to fire hazards that is attributed to the presence of more commercial spaces and flammable materials in the area.

Figure 5 shows the number of families that are usually affected by the identified hazards in the component cities. Available data in the LGU further confirms City A's higher exposure to hazards due to its big population and the number of families residing in flood-prone areas. However, planning office from the same LGU did not provide the relevant data needed to cross-examine the exposure of other families to other hazards present in the city.

\subsubsection{Hazard/s Present}

The types of hazards experienced by the cities were determined through survey, interviews, and review of available records. The responses made by the respondents confirmed the type of hazards their locality are exposed to. Similar to the figure previously presented, all the cities experience typhoons $(\mathrm{n}=25)$ and flooding (City $\mathrm{A}$ and $\mathrm{E}=$ 5 , City $C$ and $D=4$, City $B=3$ ). Other hazards such as landslides (City $\mathrm{D}=2$, City $\mathrm{E}=4$ ), liquefaction (City $\mathrm{A}=$ 1 , City $\mathrm{D}=2$ ), and vehicular accidents (City $\mathrm{D}=1$ ) also emerged. Analysis of data from the survey and interviews revealed that there are cities with mountainous areas that are prone to landslides. In addition to measures implemented for typhoons and flooding, these cities also have activities for management of landslides. Liquefaction, on the other hand, is common to communities near the sea or other waterbodies. Most cities (City B, C, and E) do not consider this as disaster risk.

\subsubsection{Capacity}

It is important to emphasize people's capacity to anticipate, cope with, resist, and recover from disasters, rather than simply focus on the vulnerability that limits them. Like vulnerability, capacity depends on social (social relations, leadership, management capacities), economic (partnership mechanisms), political (presence of institutionalized DRRM and planning offices, hiring of personnel with technical know-how), psychological (human knowledge and skills), environmental (environmental policies and programs), and physical assets (equipage) and other good governance approaches (DFID 2004; UNISDR 2017).
Fig. 4 The number of barangays exposed to hazards in each component city in Nueva Ecija (City A-Cabanatuan; City B-Gapan; City CPalayan; City D-San Jose; City E-Science City of Muñoz)

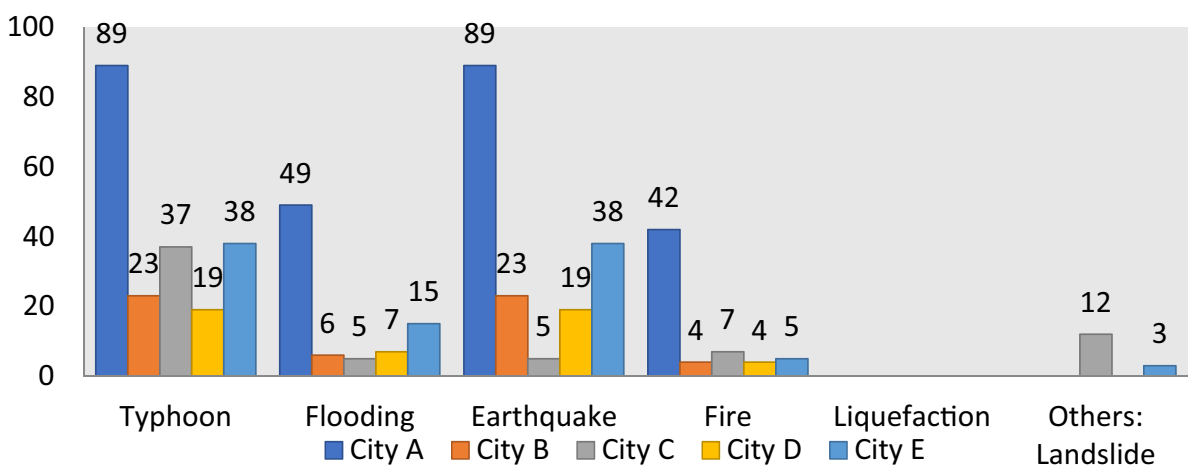


Fig. 5 The number of families exposed to hazards in component cities of Nueva Ecija (City A-Cabanatuan; City BGapan; City C-Palayan; City D-San Jose; City E-Science City of Muñoz)

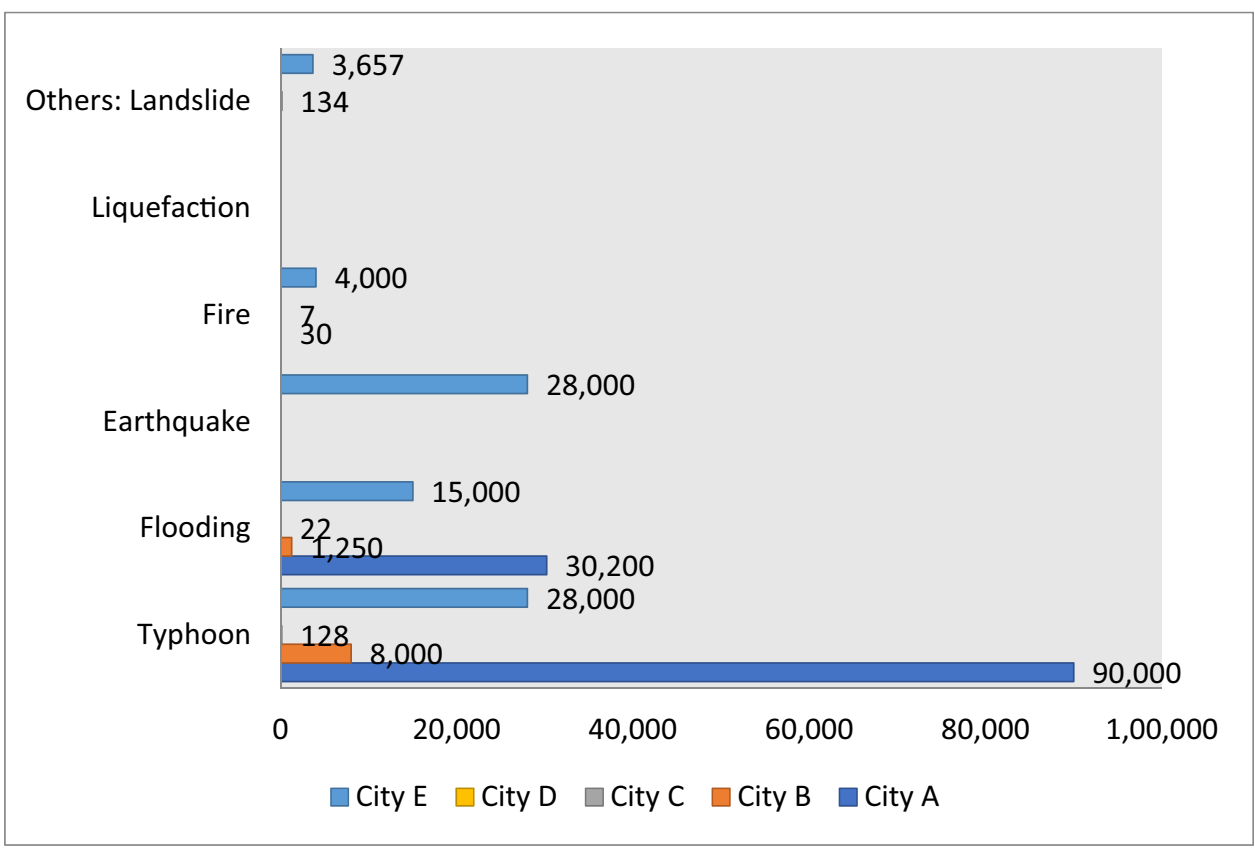

Of all the cities, only City D ( $n=5)$ was able to satisfy all the following criteria: (1) institutionalized DRRM office; (2) availability of plantilla position for DRRM officers; (3) functional DRRM council; (4) equipage; (5) recipient of good governance awards such as Seal of Good Local Governance (SGLG) and Gawad KALASAG (Kalamidad at Sakuna Labanan Sariling Galing ang Kaligtasan); and (6) availability of Comprehensive Development Plan (CDP), Local DRRM Plan (LDRRMP), and Local Climate Change Action Plan (LCCAP). The city's big population, wide land area, experiences from previous calamities, and the political will of the present administration are among the factors that compel the local government unit to comply with the mandates of Republic Act 10121 and prepare for disasters. Nonetheless, in spite the awards and compliance, the DRR system implemented in the area is at the initial stage and the sustainability of the plans formulated has not been established. Comparatively, City A almost meets the criteria except the SGLG award mainly because its revised Comprehensive Land Use Plan (CLUP) has not been approved and implemented. All of the cities agreed that the programs and activities related to DRR-CCA incorporated on their CDPs are based on their previous disaster experiences.

Two of the cities have been Gawad KALASAG awardees (City A and D). Gawad KALASAG is an award given to institutions, agencies, groups, and individuals with significant contribution on DRRM and humanitarian activities. All nominees are thoroughly screened. The documents submitted are reviewed and actual field validation is conducted. The validation process serves as a good tool for the assessment of the LGUs' DRR and CCA initiatives guided by the National DRRM Framework. Having received such award also presupposes the positive capacity of LGUs and their compliance to other statutory requirements such as Accessibility Act, Fire Code, and Building Code.

One LGU (City C) still lacks plantilla or regular position for DRRM officers. The DRRM officers are the people with knowledge and expertise that are important for ensuring the safety of the communities against hazards. It is quite surprising that LGUs still do not have enough human resources with technical expertise on DRR-CCA eight years after the passage of Republic Act 10121. To increase the coping capacity of the community, the identified hazards should be considered in the local plans. Favorably, all respondents agreed that all hazards previously mentioned were considered and incorporated in the LDRRMP, LCCAP, and CDP among others. The LGUs also invest in enhancing the capacity of personnel by appropriating funds for orientations, seminars, and trainings consistent with the dictum of the Weber's bureaucratic model where skills and expertise must be compatible with the task to be performed (Serpa and Ferreira 2019). However, the availability of plantilla item remains a common issue across LGUs.

\subsubsection{Profile of City Planning and Development Office (CPDO) and City Disaster Risk Reduction and Management Office (CDRRMO) Planning Officers}

Local planners and DRRM officers are responsible for setting the direction, development, implementation, and coordination of programs and activities. Therefore, as 
managers, they must be knowledgeable on the planning process as they are part of the team that formulates and implements essential programs and activities.

3.1.5.1 Plantilla Position The responses to both the survey questionnaire and the interview questions reflect that while the LGUs have plantilla (regular/permanent positions) for CDRRMOs and CPDOs, the available positions are limited. Common problems stem from factors such as: (1) lack of funds since the LGUs' budget is dependent on the Internal Revenue Allotments and savings; (2) the DRRM offices are institutionalized but some positions are attached to the office of the Mayor; and (3) the Local Chief Executives have the final say on who will be appointed for the key positions.

In some LGUs, personnel are of temporary status (that is, those who are hired to perform functions in other office but given designation or additional duties in the CPDO or CDRRMO without additional compensation; contract workers; or those who have the same term of office as the local chief executive) since Republic Act 10121 only mandates four plantilla (regular positions). At most, they are the trusted employees of the incumbent officials. There is also high staff turnover because of the tediousness of the nature of their work. Consequently, some positions are left vacant because of lack of qualified personnel with background and experience related to the job. The findings are consistent with the study of Cuevas et al. (2015) where institutional capacity to cope with the challenges of climate change is hindered by the issue of human resources resulting from the implementation of fragmented laws and regulations in the country.

3.1.5.2 Work Experiences In terms of work experiences or length of tenure of officers who are in charge of the planning, the majority of the respondents $(n=12)$ said that they are working in the LGU for 10 years and above. Cities $\mathrm{A}, \mathrm{B}, \mathrm{C}$, and $\mathrm{E}$ have respondents $(\mathrm{n}=10)$ that occupy planning positions within 1-3 years. Only City A has personnel working in the LGU for less than a year. In terms of number of years in current position, most respondents (n $=10$ ) hold their current positions for $1-3$ years. Some are in their current positions for less than a year $(n=6)$, and 10 years and above $(n=4)$. Also, it is only City A and City D who have personnel in their current position for 4-6 years and 7-9 years respectively.

\subsubsection{Trainings and Involvement of the Respondents on} the Formulation of Local Plans In terms of trainings and involvement of the respondents on the formulation of local plans, some of the respondents have not yet undergone comprehensive DRR-CCA and planning-related trainings and lack knowledge and experience from previous disaster events that they can use as bases in the formulation of much better multi-sectoral and need-specific plans.

All the respondents from City D have undergone trainings on the planning related to the formulation of CDP, LDRRMP, and LCCAP. Respondents from City A and City $B$ have not attended any training on comprehensive development planning. Comparatively, only one respondent from City A, B, and E (20\% of the five respondents) have attended a climate change action planning training. Attendance to trainings and seminars related to their work and functions increases the capacity of LGU workers to deliver actual services to their constituents. Therefore, to develop the institution's capacity it would be better to train and enhance the capacities of the employees first. The sustainability of the plans, programs, projects, and activities relies on the capacity of workers.

\subsubsection{Level of Awareness of CPDO and CDRRMO} Planning Officers Although directly involved in the formulation of plans, new local planners and DRRM officers said that they find it difficult to digest the contents of existing guidelines. This is because the procedures and the guidelines are highly technical. Thus, they are encouraged to attend trainings and seminars especially those related to DRR and CCA (Table 1).

In spite the high percentage of trained personnel and high involvement of respondents from cities A, D, and E in the formulation of plans, most of them said that they are "very aware" but not proficient (extremely aware) on the mainstreaming of DRR-CCA in the local development plan. The level of awareness of the respondents on the inclusion of DRR-CCA in the CDP was determined using a five-point Likert-type scale questionnaire. The result of the analysis is quantified in Table 2.

Awareness on the provisions of Republic Act 10121 got a mean response of 5 (City A), 4.2 (City E), 4 (City B), and 3.8 (City $\mathrm{C}$ and D). But the mean scores are lower when it comes to the provisions of the Act regarding the mainstreaming of DRR and CCA in development process and policy formulation and budgeting (City $\mathrm{A}$ and $\mathrm{E}=4.2$; City $\mathrm{D}=3.8$; City $\mathrm{C}=3.2$; and City $\mathrm{B}=2.8$ ).

In spite their direct involvement in the planning process, respondents from City B and C said that they are only "moderately aware" of the concept of mainstreaming. The information provided by the respondents support the idea that DRR mainstreaming in the province is in its initial stages. It also reflects that the insufficient experience of the personnel and their limited knowledge of the concepts and procedures (existing policies, budget requirements, assessment process, and their actual applications) are essential to improve the quality of the plan and the public service as a whole. 
Table 1 Demographic profile of component cities in Nueva Ecija

\begin{tabular}{lccccc}
\hline & City A (Cabanatuan) & City B (Gapan) & City C (Palayan) & City D (San Jose) & City E (Science City of Muñoz) \\
\hline Population & 302,000 & 97,234 & 82,524 & 41,041 & 144,780 \\
Number of Barangays & 89 & 23 & 37 & 19 & 38 \\
Density (per km ${ }^{2}$ ) & 1571 & 591 & 506 & 405 & 778 \\
\hline
\end{tabular}

Table 2 Level of awareness of the respondents on the inclusion of disaster risk reduction and climate change adaption (DRR-CCA) in the Comprehensive Development Plan

\begin{tabular}{|c|c|c|c|c|c|}
\hline & \multicolumn{5}{|c|}{ Level of awareness (weighted mean) } \\
\hline & $\begin{array}{l}\text { City A } \\
\text { (Cabanatuan) }\end{array}$ & $\begin{array}{l}\text { City B } \\
\text { (Gapan) }\end{array}$ & $\begin{array}{l}\text { City C } \\
\text { (Palayan) }\end{array}$ & $\begin{array}{l}\text { City D } \\
\text { (San } \\
\text { Jose) }\end{array}$ & $\begin{array}{l}\text { City E } \\
\text { (Science } \\
\text { City of } \\
\text { Muñoz) }\end{array}$ \\
\hline $\begin{array}{l}\text { a. Are you acquainted with Republic Act } 10121 \text { or the Philippine } \\
\text { DRRM Act of 2010? }\end{array}$ & 5 & 4 & 3.8 & 3.8 & 4.2 \\
\hline $\begin{array}{l}\text { b. Do you have knowledge on the provisions of Republic Act } 10121 \\
\text { regarding the mainstreaming of DRR-CCA in development process } \\
\text { and policy formulation and budgeting? }\end{array}$ & 4.2 & 2.8 & 3.2 & 3.8 & 4.2 \\
\hline $\begin{array}{l}\text { c. Do you have knowledge on how to mainstream DRR-CCA in the } \\
\text { local policies, plans, and budget? }\end{array}$ & 4 & 2.5 & 3.67 & 3.6 & 4.4 \\
\hline d. Are you aware of the Climate and Disaster Risk Assessment process? & 3.4 & 2.75 & 3.75 & 3.6 & 4 \\
\hline $\begin{array}{l}\text { e. Are you aware of the linkage between DRR-CCA and the } \\
\text { Comprehensive Development Plan? }\end{array}$ & 3.4 & 2 & 3.6 & 3.4 & 4 \\
\hline $\begin{array}{l}\text { f. Are you acquainted with National Disaster Risk Reduction and } \\
\text { Management Council (NDRRMC), Department of Budget and } \\
\text { Management (DBM), Department of the Interior and Local } \\
\text { Government (DILG) Joint Memorandum Circular No. 2013-1 } \\
\text { regarding Allocation and Utilization of the Local DRRM Fund? }\end{array}$ & 4 & 2.4 & 2.8 & 3.4 & 4.2 \\
\hline $\begin{array}{l}\text { g. Are you familiar with DBM, Climate Change Commission (CCC), } \\
\text { DILG Joint Memorandum Circular No. 2014-01 regarding Tagging/ } \\
\text { Tracking Climate Change Expenditures in the Local Budget? }\end{array}$ & 3.6 & 2.2 & 2.8 & 3 & 4.4 \\
\hline h. TOTAL Weighted Mean & 3.94 & 2.66 & 3.37 & 3.51 & 4.20 \\
\hline Verbal Interpretation & Very aware & $\begin{array}{l}\text { Moderately } \\
\text { aware }\end{array}$ & $\begin{array}{l}\text { Moderately } \\
\text { aware }\end{array}$ & $\begin{array}{l}\text { Very } \\
\text { aware }\end{array}$ & Very aware \\
\hline
\end{tabular}

1-1.8 (Unaware), 1.81-2.60 (Slightly Aware), 2.61-3.40 (Moderately Aware), 3.41-4.20 (Very Aware), and 4.21-5.00 (Extremely Aware)

\subsubsection{Inclusion of Disaster Risk Reduction and Climate Change Adaptation into the Comprehensive Development Plan}

\subsubsection{Disaster Prevention and Mitigation Risk assess-} ment, hazard mapping, budget allocation, risk financing and insurance, flood control projects, and involvement of people's organizations and vulnerable sectors in development planning are some of the elementary but crucial measures that must be taken to prevent and mitigate disasters. Proactive implementation of such measures not only promotes the welfare of the public but also fosters environmental conservation and good governance through proper management of resources.

All the cities mentioned that they: (1) conduct risk assessment on a regular basis; (2) have available hazard, vulnerability, capacity, and resource maps; (3) have a database of elements at risk; (4) have integrated/mainstreamed disaster mitigation measures in the Comprehensive Land Use Plan and Annual Investment Plan; (5) have updated zoning ordinance, safety regulations, environmental ordinances, environmental policies (infrastructure resilience, inspection, construction, maintenance); (6) involve the nongovernmental organizations (NGOs), people's organizations (POs), women, youth, religious, 
business, and the other sectors (for example, farmers, urban poor, indigenous peoples, migrant workers, students, senior citizens, persons with disabilities); (7) conduct hazard mapping, risk profiling/community-based monitoring system, construction, evaluation of building integrity; and (8) implement provisions on the prohibition of illegal settlements on or near bodies of water. The respondents also said that their respective LGUs appropriate funds for the strengthening of the early warning system and flood control structures (dikes, dams).

These activities are multi-sectoral and multi-faceted. Ideally, these are among the basic measures that LGUs observe to mitigate or lessen the intensity and impact of disasters thus, the common answer of "Yes" in almost all items. Among the respondents, only one respondent from City A answered "No" when asked whether they conduct maintenance activities and whether these are included in the CDP. They do not include a separate maintenance activity for the prevention and mitigation phase since the bulk of the activity is done during rehabilitation and recovery phase. During the interview, the respondent also mentioned that most of their equipment are new and still under warranty. Allocation for their maintenance activities is included in the Annual Investment Plan and not funded through the CDP. This means that all cities have included in their CDP the activities that aim to prevent and mitigate the impact of disasters and climate change in their localities. This finding is supported by the secondary data collected from the planning office of each city.

\subsubsection{Disaster Preparedness Republic Act 10121} mandates every LGU to implement the listed activities on a regular basis. All respondents agreed that the activities listed on the questionnaire must be conducted and completed prior to the occurrence of natural hazards and disasters that are often unpredictable.

In terms of the inclusion of DRR and CCA in the area of disaster preparedness, all five cities mentioned that they have (1) executive order / resolution / ordinance organizing the City Disaster Risk Reduction and Management Council (CDRRMC); (2) regular council meetings; (3) funds for DRR-CCA related trainings; (4) web page / Facebook page for DRR-CCA related equipage and facilities; (5) information and education campaigns for DRR and CCA; (6) activities for the stockpiling and prepositioning of relief goods; and (7) approved evacuation and contingency plans.

They also conduct activities related to risk reduction including: (1) climate-proofing of equipment and facilities; (2) coordination and partnership with other agencies; (3) creation of taskforce for the implementation of DRR-CCA activities; (4) enactment of local environment ordinances; and (5) strict implementation of Building Code, Fire Code,
Ecological Solid Waste Management Act (Republic Act 9003).

The respondents' mean response of "Yes" on all items is consistent with the information collected in terms of awards received, training attended, and equipage. It appears that the five cities already have plans in place and are capable of dealing with the effects and impacts of disasters and climate variability.

3.1.6.3 Disaster Response The capacity of the LGUs to respond to a disaster is measured not only through the availability of both human and material resources but also on their capability to effectively mobilize key stakeholders. The respondents were asked whether they have internal systems in place such as real-time or end-to-end reporting system. All the respondents from the five cities answered "Yes," which is validated through review of supporting documents such as Incident Action Plans, Standard Operating Procedures, and written evacuation and relief distribution protocols, among others. The respondents also agreed that their existing reporting and localized incidentspecific management systems standardize their rescue or response actions. However, most of the respondents said that not all plans are religiously updated. Nonetheless, they confirmed that it has only been 1 to 2 years ago since their plans were last updated and that those were still congruent with the contents of the CDP.

3.1.6.4 Disaster Rehabilitation and Recovery The mainstreaming of DRR-CCA in the CDP in this thematic area employs the "Build-Back Better" principle of the national government. The responses of the respondents confirmed that the principle is translated into tangible activities to ensure that affected communities can return to their normal ways of living immediately after a calamity or disaster.

Not all DRR-CCA activities of the LGUs may be funded through the Annual Investment Plan due to budget limitations, hence, major activities that are in accordance with the development thrusts of the local governments are mainstreamed into the CDP for funding and implementation. Apparently, all cities have included in their CDPs different rehabilitation and recovery programs. This is reflected in their mean response of "Yes" to all the questions on the survey. Based on their responses, the following activities are included in the CDP: (1) restoration and rehabilitation activities; (2) post-disaster needs assessment; (3) recovery plan; (4) volunteer rehabilitation works (food/cash for work); (5) shelter assistance; and (6) livelihood trainings.

However, although included in the plan, the implementation relies on the availability of funds, result of postdisaster needs assessment, and damage reports. 
Conversely, because not all cities experienced major calamitous events at the time of data gathering, they were not able to present recent supporting documents that will further triangulate the responses made by the city planners and DRRM officers.

\subsubsection{Analysis on the Relationship Between Disaster Risk Profile and the Inclusion of Disaster Risk Reduction and Climate Change Adaption into the Comprehensive Development Plan}

To make a more in-depth analysis, this study looked into the significant relationship between the capacity, exposure, vulnerability, and hazard of the areas covered in the study. These variables are depicted in the disaster risk profile of the five component cities. The correlation between the data pertaining to the disaster risk profile and the inclusion of DRR-CCA to the Comprehensive Development Plan are also established using Spearman's rank correlation coefficient. Given the sample population of 25 and the dichotomous variables used in the analysis of data, the nominal measurements are converted into ordinal scales to satisfy the criteria for the use of the Spearman's rank correlation coefficient. The results generated from the analysis of variables are presented in Table 3.

The analysis of the relationship between the inclusion of DRR and CCA into the CDP and the components of disaster risk revealed that as the capacity, exposure, and hazard of the community or LGU increases, so does the inclusion of DRR and CCA into the CDP (strongly positive correlation of $0.67,0.6$, and 0.53 ).

However, the context is different when it comes to the relationship between vulnerability and the inclusion of DRR and CCA into the CDP. Analysis of the variables revealed the inverse relationship between the two. While the respondents acknowledge the vulnerabilities (limited capacity to anticipate, cope with, resist, and recover from the impact of disasters) of their respective localities, they affirm that the LGUs include DRR and CCA activities in the CDP. In spite not having technical expertise on the formulation of development and DRRM plans, the prime bases for inclusion are the previous disaster experiences and assessed needs of the hazard-prone communities. Also considered in the development planning are the global warming trend and weather extremes.

\section{Conclusion and Recommendations}

This study assessed the level of mainstreaming of disaster risk reduction and climate change adaptation measures into the Comprehensive Development Plan of the component cities in the province of Nueva Ecija in the Philippines. It also discussed how DRR-CCA related policies and initiatives have evolved and continuously progress in response to the threats posed by the global warming, climate change, and human-made hazards.

The responses of the personnel surveyed and interviewed confirmed the type of hazards that their areas are exposed to. Almost all barangays of the component cities except City $\mathrm{C}$ with high terrains are exposed to the effects of typhoons, flooding, and earthquakes. At present, all cities are expanding their urban areas through the erection of more commercial and residential buildings. These urban areas are not spared from the natural hazards and unfortunately, have higher likelihood of incurring more economic losses once hit by natural calamities due to the higher vulnerability associated with densely populated areas.

Mainstreaming disaster risk reduction and climate change adaptation into the local development planning process is considered first line of defense to abate the negative consequences of the global warming of $1.5{ }^{\circ} \mathrm{C}$. While delving deeper into the level of mainstreaming of disaster risk reduction and climate change adaptation into the local development planning of the component cities of Nueva Ecija, we found that each LGU is mandated under Republic Act 10121 to prepare a Comprehensive Development Plan (CDP), a six-year or medium-term development plan, and to integrate sectoral and thematic concerns.

All of the cities also affirm that the programs and activities related to DRR-CCA mainstreamed into their CDPs are based on the communities' previous disaster experiences. Notwithstanding the compliance of, and the

Table 3 Results of the Spearman's rank correlation analysis

\begin{tabular}{ll}
\hline $\begin{array}{l}\text { Correlation between the Inclusion of Disaster Risk Reduction and Climate Change Adaption (DRR-CCA) } \\
\text { into the Comprehensive Development Plan (CDP) }\end{array}$ & $\begin{array}{l}\text { Spearman's Rank Correlation } \\
\text { Coefficient }\left(r_{\mathrm{s}}\right)\end{array}$ \\
\hline Capacity & $r_{\mathrm{s}}=0.67$ \\
Exposure & $r_{\mathrm{s}}=0.6$ \\
Vulnerability & $r_{\mathrm{s}}=-0.8$ \\
Hazard & $r_{\mathrm{s}}=0.53$ \\
\hline
\end{tabular}


awards received by the LGUs, the DRR systems implemented in their areas are at the initial stages. Moreover, the sustainability of the plans formulated has not been established. Based on the findings, the personnel involved in the formulation of the local plans are either "moderately aware" or "very aware" of the technicalities involved in the preparation of the Comprehensive Development Plan (CDP), Local DRRM Plan (LDRRMP), and Local Climate Change Action Plan (LCCAP). Such limitations may jeopardize the quality of plans produced by the LGUs and therefore, insufficient to address the true needs of the public.

Positively, the cities covered affirm that their LGUs are now investing in activities related to knowledge and resource building. Nonetheless, aside from the CDRRMOs and CPDOs, community stakeholders must also receive trainings on the preparation and implementation of plans and DRR-CCA related activities. This is because they have the first-hand knowledge of the situation in the community and are responsible for the management of community resources.

Other issues confronting the LGUs are limited plantilla positions for DRRM officers and city planners. The executive and legislative departments should therefore consider the regularization of employees involved in development planning and DRRM to boost their morale and minimize high turnover rate among technical staff.

Worth highlighting is the inverse relationship between the vulnerability of the five cities and the inclusion of DRR and CCA into the LGUs' CDP. The results show that the respondents acknowledge the vulnerabilities of their respective areas, and the inclusion of the DRR and CCA activities in the CDP is done. This, however, remains at the level of compliance in planning. The findings suggest that the presence of DRR and CCA plan does not necessarily mean that the community has lesser vulnerability or higher level of readiness. This is a gap in the mainstreaming of DRR-CCA policy implementation, which requires further study and more cases of validation on the ground.

Open Access This article is licensed under a Creative Commons Attribution 4.0 International License, which permits use, sharing, adaptation, distribution and reproduction in any medium or format, as long as you give appropriate credit to the original author(s) and the source, provide a link to the Creative Commons licence, and indicate if changes were made. The images or other third party material in this article are included in the article's Creative Commons licence, unless indicated otherwise in a credit line to the material. If material is not included in the article's Creative Commons licence and your intended use is not permitted by statutory regulation or exceeds the permitted use, you will need to obtain permission directly from the copyright holder. To view a copy of this licence, visit http://creativecommons. org/licenses/by/4.0/.

\section{References}

Blakely, E.J., and N.G. Leigh. 2010. Planning local economic development: Theory and practice. Thousand Oaks, CA: Sage Publications.

Bonett, D.G., and T.A. Wright. 2000. Sample size requirements for estimating Pearson Kendall and Spearman correlations. Psychometrika 65(1): 23-28.

Cambridge Centre for Risk Studies. 2018. Global risk index 2019. Executive summary. Cambridge Centre for Risk Studies, University of Cambridge. https://www.jbs.cam.ac.uk/fileadmin/ user_upload/research/centres/risk/downloads/crs-global-riskindex-exec-summary-2019.pdf. Accessed 10 Mar 2020.

Center for Excellence in Disaster Management and Humanitarian Assistance. 2018. Philippines: Disaster management reference handbook 2018. https://reliefweb.int/sites/reliefweb.int/files/ resources/Philippines_2018-0318.pdf. Accessed 28 Dec 2018.

Climate Change Commission. 2012. Philippines: National climate change action plan 2011-2018. https://www.scribd.com/docu ment/93600643/Nation-ClimateChange-Action-Plan-2011-2028. Accessed 28 Dec 2018.

Climate Change Commission. 2017. Accessing the People's Survival Fund (PSF): Communities for resilience. https://climate.gov.ph/ files/3-PSF.pdf. Accessed 20 Apr 2021.

Cohen, J.W. 1988. Statistical power analysis for the behavioral sciences, 2nd edn. Hilldales, NJ: Lawrence Erlbaum Associates.

Congress of the Philippines. 2010. Republic act No.10121: Philippine disaster risk reduction and management act of 2010. Quezon City, The Philippines. http://www.ndrrmc.gov.ph/attachments/ article/45/Republic_Act_10121.pdf. Accessed 22 Dec 2018.

CRED (Centre for Research on the Epidemiology of Disasters). 2016. EM-DAT (Emergency Events Database). Brussels, Belgium: CRED.

Cuevas, S.C., A. Peterson, C. Robinson, and T.H. Morrison. 2016. Institutional capacity for long-term climate change adaptation: Evidence from land use planning in Albay, Philippines. Regional Environmental Change 16: 2045-2058.

DFID (Department for International Development). 2004. Disaster risk reduction: A development concern. London: DFID.

DILG (Department of the Internal and Local Government). 2015. Local planning illustrative guide: Preparing and updating the Comprehensive Development Plan (CDP). https://www.dilg.gov. ph/PDF_File/reports_resources/dilg-reports-resources-2017110_ 298b91787e.pdf. Accessed 2 Jan 2019.

Gabriel, A.G. 2017. Transparency and accountability in local government: Levels of commitment of municipal councilors in Bongabon in the Philippines. Asia Pacific Journal of Public Administration 39(3): 217-223.

Gabriel, A., and T. Mangahas. 2017. Indigenous people's contribution to the mitigation of climate variation, their perception, and organizing strategy for sustainable community based forest resources management in Caraballo Mountain, Philippines. Open Journal of Ecology 7: 85-100.

Güneralp, B., I. Güneralp, and Y. Liu. 2015. Changing global patterns of urban exposure to flood and drought hazards. Global Environmental Change 31: 217-225.

Heintze, H.J., L. Kirch, B. Entwicklung, B. Küppers, H. Mann, F. Mischo, P. Mucke, T. Pazdzierny, et al. 2018. World risk report 2018. Bündnis Entwicklung Hilft and UNU-EHS. https:// reliefweb.int/sites/reliefweb.int/files/resources/WorldRiskRe port-2018.pdf. Accessed 21 Apr 2021.

Hinkel, J. 2011. "Indicators of vulnerability and adaptive capacity": Towards a clarification of the science-policy interface. Global Environmental Change 21(1): 198-208. 
IOM (International Organization for Migration). 2010. The future of migration: Building capacities for change. https://publications. iom.int/system/files/pdf/wmr_2010_english.pdf?language=en. Accessed 2 Jan 2019.

IPCC (Intergovernmental Panel on Climate Change). 2013. Climate change 2013: The physical science basis. Contribution of Working Group I to the fifth assessment report of the Intergovernmental Panel on Climate Change. Cambridge: Cambridge University Press.

IPCC (Intergovernmental Panel on Climate Change). 2018. Summary for policymakers. In Global warming of $1.5^{\circ} \mathrm{C}$. An IPCC special report on the impacts of global warming of $1.5^{\circ} \mathrm{C}$ above preindustrial levels and related global greenhouse gas emission pathways, in the context of strengthening the global response to the threat of climate change, sustainable development, and efforts to eradicate poverty. Geneva: World Meteorological Organization. https://www.ipcc.ch/site/assets/uploads/sites/2/ 2018/07/SR15_SPM_version_stand_alone_LR.pdf. Accessed 21 Apr 2021.

NDRRMC (National Disaster Risk Reduction and Management Council) and OCD (Office of Civil Defense) Planning Division. 2009. Strengthening disaster risk reduction in the Philippines: Strategic national action plan, 2009-2019. Metro Manila, Philippines: NDRRMC and OCD.

NDRRMC (National Disaster Risk Reduction and Management Council). 2011a. NDRRMF (National Disaster Risk Reduction and Management Framework). http://www.ndrrmc.gov.ph/attach ments/article/1675/NDRRMC_Framework.pdf. Accessed 22 Dec 2018.

NDRRMC (National Disaster Risk Reduction and Management Council). 2011b. National Disaster Risk Reduction and Management Plan (NDRRMP) 2011-2028. http://ndrrmc.gov.ph/ attachments/article/41/NDRRM_Plan_2011-2028.pdf. Accessed 22 Dec 2018.

Ojo, E.O. 2005. Institutionalising disaster risk in Ilesha local government, Osun State, Nigeria. Presented at the National Platform for Stakeholders in Disaster Reduction, 13-14 October 2005, Abuja, Nigeria.

Palinkas, L.A., S.M. Horwitz, C.A. Green, J.P. Wisdom, N. Duan, and K. Hoagwood. 2015. Purposeful sampling for qualitative data collection and analysis in mixed method implementation research. Administration and Policy in Mental Health 42(5): $533-544$

PIDS (Philippine Institute for Development Studies). 2017. Institutional issues on disaster risk reduction and management. Discussion Paper Series No. 2017-50. https://pidswebs.pids. gov.ph/CDN/PUBLICATIONS/pidsdps1750.pdf. Accessed 28 Dec 2018.

PSA (Philippine Statistics Authority). 2017. Census of population, Report No. 2 - Demographic and socioeconomic characteristics. Nueva Ecija, June 2017. http://psa.gov.ph/sites/default/files/03_ Nueva\%20Ecija.pdf. Accessed 21 Apr 2021.

Rao, E., Y. Xiao, Z. Ouyang, and H. Zheng. 2016. Changes in ecosystem service of soil conservation between 2000 and 2010 and its driving factors in southwestern China. Chinese Geographical Science 26(2): 165-173.

ReliefWeb. 2018. Philippines: Latest typhoon-induced death toll climbs. https://reliefweb.int/report/philippines/philippines-latesttyphoon-induced-landslide-death-toll-climbs. Accessed 2 Jan 2019.
Republic of the Philippines. 1991. Republic act 7160: The local government code of 1991. Manila, The Philippines. https://www. officialgazette.gov.ph/downloads/1991/10oct/19911010-RA7160-CCA.pdf. Accessed 22 Dec 2018.

Scheffran, J., and A. Battaglini. 2011. Climate and conflicts: The security risks of global warming. Regional Environmental Change 11(1): 27-39.

Serpa, S., and C. Ferreira. 2019. The concept of bureaucracy by Max Weber. International Journal of Social Science Studies 7(2): $12-18$.

Smit, B., and J. Wandel. 2006. Adaptation, adaptive capacity and vulnerability. Global Environmental Change 16(3): 282-292.

Smit, B., O. Pilifosova, I. Burton, B. Challenger, S. Huq, R.J.T. Klein, G. Yohe, and N. Adger et al. 2001. Adaptation to climate change in the context of sustainable development and equity. In Climate change 2001: Impacts, adaptation, and vulnerability, ed. J.J. McCarthy, O.F. Canziani, N.A. Leary, D.J. Dokken, and K.S. White, 877-912. Cambridge: Cambridge University Press.

Tongco, M.D.C. 2007. Purposive sampling as a tool for informant selection. Ethnobotany Research \& Applications 5: 147-158.

Twigg, J. 2004. Disaster risk reduction: Mitigation and preparedness in development and emergency programming. London: Humanitarian Practice Network, Overseas Development Institute.

UNDP (United Nations Development Programme). 2011. Methodology for integrated local development planning - MiPRO. https:// www.undp.org/content/dam/bosnia_and_herzegovina/docs/ Research\&Publications/Democratic\%20Governance/Methodol ogy \%20for\%20Integrated\%20Local\%20Development\%20Plan ning $\% 20$ in $\% 20$ Bosnia\%20and\%20Herzegovina/MiPRO $\%$ 20Practical\%20Part\%20English.pdf. Accessed 22 Dec 2018.

UNISDR (United Nations International Strategy for Disaster Reduction). 2009. Global assessment report on disaster risk reduction: Summary and recommendations. https://www.unisdr.org/we/ inform/publications/9414. Accessed 16 Dec 2018.

UNISDR (United Nations International Strategy for Disaster Reduction). 2012. Impacts of disasters since the 1992 Rio de Janeiro Earth Summit. Rio de Janeiro: United Nations.

UNISDR (United Nations International Strategy for Disaster Reduction). 2015. Global assessment report on disaster risk reduction 2015. https://www.unisdr.org/we/inform/publications/42809. Accessed 16 Dec 2018.

UNISDR (United Nations International Strategy for Disaster Reduction). 2017. UNISDR annual report 2017. https://www.unisdr. org/files/58158_unisdr2017annualreport.pdf. Accessed 16 Dec 2018.

World Bank. 2010. A strategic approach to climate change in the Philippines. http://siteresources.worldbank.org/INTPHILIP PINES/Resources/PH_Low_Carbon_Transport_and_Power.pdf. Accessed 2 Jan 2019.

World Bank. 2013. Getting a grip on climate change in the Philippines: Executive report. http://documents.worldbank.org/ curated/en/473371468332663224/Gettinga-grip-on-climatechange-in-the-Philippines-executivereport. Accessed 20 Apr 2021.

Zhang, W., Z. Wei, B. Wang, and X. Han. 2016. Measuring mixing patterns in complex networks by Spearman rank correlation coefficient. Physica A: Statistical Mechanics and its Applications 451: 440-450. 